\title{
Nutrition assessment of new created mulberry varieties
}

\author{
N. O. Rajabov 1,*, V. K. Raxmonberdiyev ${ }^{1}$, B. U. Nasurillayev ${ }^{2}, Y . Y$. Mirzayeva ${ }^{1}, M . K H$. \\ Bobomurodov $^{3}$, and U.T. Absalomov ${ }^{1}$ \\ ${ }^{1}$ Tashkent State Agrarian University, Universitetskaya str., 2, 100140, Tashkent, Uzbekistan \\ ${ }^{2}$ Silk Scientific-Research Institute, Ipakchi str., 2, Tashkent, Uzbekistan \\ ${ }^{3}$ Termiz branch of Tashkent State Agrarian University, Yangiobod str., Surkhandarya, Uzbekistan
}

\begin{abstract}
This research was aimed at establishing high-quality and abundant cocoon cultivation in the country, to create new high-quality and nutritious mulberry varieties and gradually introduce them into production. In order to create local mulberry varieties, for the first time the viability of mulberry silkworm hybrids of mulberry varieties "Jararik-9", "Jararik-10" was determined by the level of cocoon productivity and technological impact. The coefficient of leaves eating of new varieties of mulberry "Jararik-9", "Jararik-10" by hybrid worms of silkworm was determined. The varieties of mulberry belonging to the genus Morus alba $L$. and hybrids belonging to the genus Bombyx mori $L$ of the mulberry silkworm were taken as the study objects. For chemical analysis, leaf samples were taken and analyzed in the spring in the order established by the worms in the middle of the 5th year of development. Furthermore, the effect of new mulberry varieties on the growth dynamics of worm leaves was studied. The coefficient of leaves eating of new mulberry varieties by hybrid worms was determined. According to the results of the research, among the new selection numbers №3-02 and №7-02, the coefficient of assimilation of №3-02 and №7-02 is significantly higher than other selection numbers and "Tajik seedless" variety.
\end{abstract}

\section{Introduction}

In order to achieve high cocoon yields, it is necessary to create new high-yielding and nutritious mulberry varieties in the silkworm breeding base and to organize intensive mulberry plantations on their basis. Therefore, the creation of new high-yielding varieties and hybrids of mulberry species Morus 1 and 2, as well as the creation of new mulberries and increase the cocoon productivity of silkworm hybrids is of great scientific and practical importance. Today, Uzbekistan is taking comprehensive measures to develop silkworm breeding, in particular, to create new varieties of mulberries suitable for silkworm hybrids $[1,5-7]$. At the same time, it is vitally important to investigate the mechanisms of improving the productivity of mulberry varieties, the impact of new mulberry varieties on the productivity and postembryonic viability of mulberry silkworm industry hybrids and 
further development of scientific research and innovations to increase their efficiency. The Action Strategy for the Development of the Republic of Uzbekistan for 2017-2021 [2, 5] pays special attention to the development of agriculture, especially livestock, including silkworm breeding. In this regard, it is pivotal to conduct research on the strengthening of the nutritional base of mulberry silkworms in the field of silkworm breeding and mulberry towards the creation and introduction into production of new varieties with high productivity, nutritional and nutritional properties. The number of scientific researches has been carried out on the creation of a number of mulberry varieties based on the care of industrial hybrids of mulberry silkworm, mainly free-pollinated mulberry leaves, and the advantages of the new mulberry hybrid and the production of different planting schemes of mulberry varieties $[3,6]$. It is also scientifically well researched by a number of foreign authors that the selection lines of mulberry belonging to the Morus alba L. variety worldwide are suitable for different regions of the world and for different worm feeding seasons, long water storage properties and nutritional traits. The most pressing issues today in the country is the establishment of high-quality and abundant cocoon plantations, the creation and gradual introduction of new quality and nutritious leafy mulberry varieties, and their superiority over local mulberry varieties imported from China [2]. Therefore, this research was intended to implement the tasks set out in the decisions "On additional measures for the further development of the silk industry"[4-5], and investigate an influence of mulberry silkworm hybrids, especially "Jararik-9" and "Jararik-10" on the viability, cocoon productivity and technological characteristics of mulberry varieties [8-9].

\section{Materials and methods}

The varieties of mulberry belonging to the genus Morus alba L. and hybrids belonging to the genus Bombyx mori $L$ of the mulberry silkworm were taken as the study objects. In our country, silkworm breeding has been practiced for many years, feeding silkworms was carried out mainly in the spring. However, the natural climatic conditions of Uzbekistan allow silkworms to be fed in late summer and early autumn. As a result of research, scientists of the Silk Road Research Institute have proved that it would be possible to feed silkworms in the foothills of the country. In the rest of the region, due to the high temperature and low humidity, mulberry silkworm rearing is a bit complicated. As a result, there was a demand for varieties and hybrids of mulberry, which are suitable for feeding silkworms in different seasons. Newly released mulberry varieties of different regions of the country were characterized by a sharp continental climate, resistance to severe frosts and high leaf yields. Mulberry is a nutrient for the silkworm, and the mulberry leaf that enters the worm's body undergoes a complete transformation as a result of being absorbed into the worm's body and decomposed [3-4,9]. At the same time, directly affecting the growth and development of food worms, the adaptability of the silkworm organism to the feed composition can be observed.

Because the chemical composition of mulberry leaves varies, the level of nutrients is also not naturally the same. This, of course, depends on the mulberry variety, the origin of the variety, the ancestors originally selected as the selection material, and the intensity of photosynthesis that occurs in mulberry leaves [1]. The dynamics of growth and development of silkworms is influenced by the quantity and quality of this or that substance

* Corresponding author: n.o.rajabov@yandex.uz 
in different mulberry varieties. As a result, the worms sometimes grow slowly, prolong the life of the young, and do not gain enough weight with age. Mulberry varieties, in addition to their leaf yield and other morpho-physiological characteristics, should be different and superior to other previously created varieties in the chemical composition of the leaf. Determination of these parameters is carried out by chemical analysis of the leaf. In this case, the amount of nitrogen in the leaves plays a big role [2]. Because this important component is involved in protein biosynthesis in the silkworm of the worm. In addition, the amount of carbohydrates in the leaf, their quality is the factors that determine the viability of silkworms and cocoon productivity.

In this research, the chemical composition of the new varieties №3-02 (Jararik-9) and №7-02 (Jararik-10) was studied. The research used generally accepted agro-technical rules in mulberry and silkworm breeding, processing and comparison of the obtained numbers by biological statistical methods, as well as "Agrotechnics for the care of white silkworm hybrids" [2-3]. These mulberry varieties were cultivated according to the same agronomic rules. Changes in the amount of water and chemicals in the leaves of varieties, the sensitivity of varieties to various factors of the external environment in the spring and a number of morpho-physiological characteristics were studied. For chemical analysis, leaf samples were taken and analyzed in the order established in the middle of the fifth age of worm development in the spring (Figure1). In spring worm feeding after commissioning in 2017 and 2018, i.e. in the middle of the fifth age of worm development, $100 \mathrm{~g}$ of leaf samples were taken from each variety at $8 \mathrm{am}$. The leaves were dried and chemical analysis was performed.Chemical analysis revealed moisture content in crude samples, crude ash content (consumption), total nitrogen, crude protein (proteins), and polyprenol, $\beta$-sitosterol, and vitamin A [4], which were primarily secondary metabolites. Table 1 and 2 showed that the amount of chemicals in the leaves of mulberry varieties in the spring of 2017-2018.

Along with food intake and its digestion, its effect on worm growth and development was of great physiological importance. Mulberry silkworm growth is inseparable from development. Because these two physiological processes are completely interrelated [8]. The growth of an organism occurs mainly by the occurrence of three processes: 1) cell proliferation; 2) cell growth; 3) increase in the mass of intercellular products. Silkworm growth can be determined in two different ways: 1) measuring the length of the worms by age; 2) Determining the weight of worms by age. In the research experiments, it was decided to determine the effect of the leaves of new mulberry varieties on the growth and development of silkworms by changing the weight of the worms at a young age.

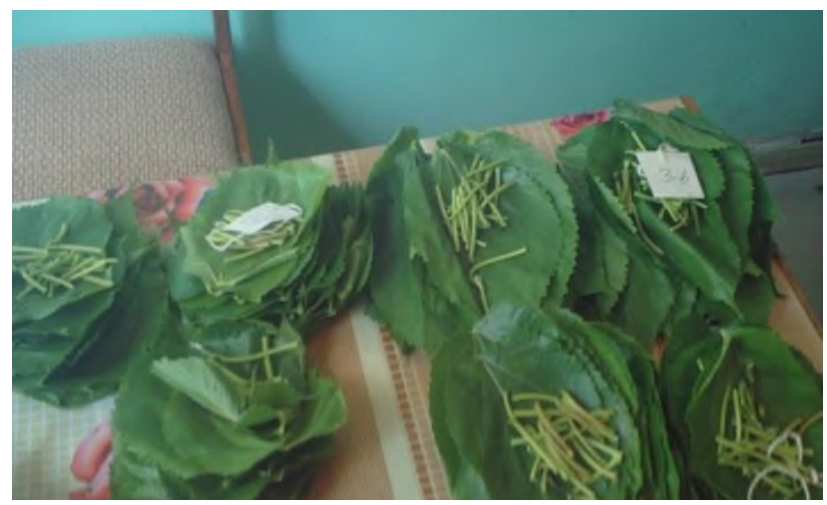

Fig. 1. Leaf samples of new mulberry varieties 


\section{Results and discussion}

\subsection{The chemical composition of the leaves of the new selection numbers of mulberry}

It was found that the chemical composition of the leaves of mulberry varieties, "Jarariq9" (sample 5) and "Jarariq-10" (sample 6), which were used in the analysis in 2017-2018, significantly distinguished from the control one, Tajik seedless (Tajikskaya bezsemyannaya) variety (Table 1 and 2). The amount of water in the new varieties was $75.1-74.3 \%$ (2017) and 76.0-77.3\% (2018), while in the Tajik seedless variety this figure was equal to $75.2-76.2 \%$. It was $98.8 \%$ to $101.4 \%$ higher than the ccontrol. One of the most important indicators of the composition of mulberry leaves was the amount of protein (protein).The more protein in a leaf, the more intense the biosynthesis of sericin and fibroin proteins in silkworms, which feed on such leaves. The amount of protein was $22.3-22.5 \%$ in 2017 , and $22.0-22.5 \%$ in 2018 in the mulberry varieties, which was $108.4-110.8 \%$ higher than "Tajik seedless" in 2018.

The total nitrogen content in the leaves of "Jarariq-9" and "Jarariq-10" varieties was also significantly higher than in the comparative variety, accounted for $95.7-102.9 \%$ (2017) and $130.7-133.7 \%$ (2018), respectively. The composition of secondary metabolites in mulberry leaves was studied. Tables 1 an 2 depicted that the content of polyprenol, Bsitosterol and vitamin A in "Jarariq-9" and "Jarariq-10" varieties for 2017-2018 was significantly higher than "Tajik seedless". In percentage, the discrepancy was that the amount of polyprenol was up to $300.0 \%$ and the amount of $\beta$-sitosterol and vitamin A were higher up to $173.3 \%$ and $246.8 \%$, respectively, than the control. The results of the chemical composition of new high-yielding varieties of mulberry showed that the content of nutrients and secondary metabolites in the leaves of mulberry varieties were different from each other. In the spring, the leaves rich in the most essential nutrients. According to the results of experiments, the chemical composition of the leaves of new varieties depended directly on their genotype, origin. Because under the same conditions, the essential nutrients of the leaves grown in one field were significantly higher than the comparative standard "Tajik seedless" variety. Accordingly, it can be said that it would be possible to grow quality silkworm cocoons from these mulberry varieties.

Table 1. Chemical composition of the leaves of mulberry varieties, №3-02 (Jararik-9) and №7-02 (Jarariq-10), in 2017

\begin{tabular}{|c|c|c|c|c|c|c|c|c|}
\hline \multirow[b]{2}{*}{$\begin{array}{c}\text { Mulberry } \\
\text { varieties } \\
\text { and sample } \\
\text { number }\end{array}$} & \multirow[b]{2}{*}{$\begin{array}{c}\text { Worm } \\
\text { feeding } \\
\text { season }\end{array}$} & \multirow[b]{2}{*}{ 苞总 } & \multicolumn{6}{|c|}{ Due to the absolute dry matter, $\%$} \\
\hline & & & 苞 & 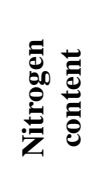 & $\frac{\bar{g}}{\frac{0}{2}}$ & $\begin{array}{l}\frac{\infty}{0} \\
\frac{0}{0} \\
\frac{0}{0}\end{array}$ & 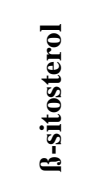 & 约茛 \\
\hline \multirow{2}{*}{$\begin{array}{c}\text { Sample } 5 \text { № } \\
\text { 3-02 (Jararik- } \\
9 \text { ) }\end{array}$} & Spring & 75.1 & 22.5 & 4.32 & 12.2 & 0.03 & 0.023 & $\begin{array}{c}35859.6 \\
0\end{array}$ \\
\hline & $\begin{array}{c}\text { Compari } \\
\text { son } \%\end{array}$ & 99.9 & 98.2 & 102.9 & 88.4 & 300.0 & 121.1 & 206.7 \\
\hline
\end{tabular}




\begin{tabular}{|c|c|c|c|c|c|c|c|c|}
\hline $\begin{array}{c}\text { Sample 6 № } \\
\text { 7-02 (Jararik- } \\
\text { 10) }\end{array}$ & Spring & 74.3 & 22.3 & 4.02 & 11.1 & 0.03 & 0.027 & 37005.0 \\
\cline { 2 - 8 } & $\begin{array}{c}\text { Compari } \\
\text { son\% }\end{array}$ & 98.8 & 97.4 & 95.7 & 80.4 & 300.0 & 142.1 & 213.3 \\
\hline $\begin{array}{c}\text { Sample 8 } \\
\text { Tajik } \\
\text { seedless } \\
\text { (control) }\end{array}$ & \begin{tabular}{c} 
Spring \\
\cline { 2 - 8 }
\end{tabular} & 75.2 & 22.9 & 4.20 & 13.8 & 0.01 & 0.019 & $\begin{array}{c}17345.2 \\
5\end{array}$ \\
\hline
\end{tabular}

Table 2. Chemical composition of leaves of mulberry varieties, № 3-02 (Jarariq 9) and № 7-02 (Jarariq 10), in 2018

\begin{tabular}{|c|c|c|c|c|c|c|c|c|}
\hline \multirow[b]{2}{*}{$\begin{array}{c}\text { Mulberry } \\
\text { varieties } \\
\text { and sample } \\
\text { number }\end{array}$} & \multirow[b]{2}{*}{$\begin{array}{c}\text { Worm } \\
\text { feeding } \\
\text { season }\end{array}$} & \multirow[b]{2}{*}{ 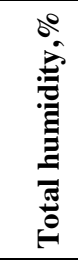 } & \multicolumn{6}{|c|}{ Due to the absolute dry matter,\% } \\
\hline & & & D. & 苞 & 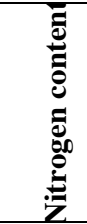 & $\frac{7}{\frac{.0}{2}}$ & $\frac{n}{0}$ & 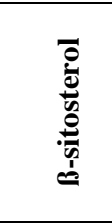 \\
\hline \multirow{2}{*}{$\begin{array}{c}\text { Sample } 5 \text { № } \\
\text { 3-02 (Jararik- } \\
\text { 9) }\end{array}$} & Spring & 76.0 & 22.0 & 3.53 & 11.34 & 0.03 & 0.026 & $\begin{array}{c}35849.4 \\
1\end{array}$ \\
\hline & $\begin{array}{c}\text { Compari } \\
\text { son } \%\end{array}$ & 99.7 & 108.4 & 130.7 & 84.6 & 100.0 & 173.3 & 239.4 \\
\hline \multirow{2}{*}{$\begin{array}{c}\text { Sample } 6 \text { № } \\
\text { 7-02 (Jararik- } \\
10 \text { ) }\end{array}$} & Spring & 77.3 & 22.5 & 3.60 & 11.05 & 0.03 & 0.025 & 36966.0 \\
\hline & $\begin{array}{c}\text { Compari } \\
\text { son } \%\end{array}$ & 101.4 & 110.8 & 133.3 & 82.4 & 100.0 & 166.7 & 246.8 \\
\hline \multirow{2}{*}{$\begin{array}{l}\text { Sample } 8 \\
\text { Tajik } \\
\text { seedless } \\
\text { (control) }\end{array}$} & Spring & 76.2 & 20.3 & 2.70 & 13.41 & traces & 0.015 & $\begin{array}{c}14977.3 \\
6\end{array}$ \\
\hline & $\begin{array}{c}\text { Compari } \\
\text { son } \%\end{array}$ & 100.0 & 100.0 & 100.0 & 100.0 & - & 100.0 & 100.0 \\
\hline
\end{tabular}

\subsection{Influence of leaves of new mulberry varieties on worm growth dynamics}

Determining the growth dynamics in the IV-V age range showed that how effective mulberry varieties were. The weight gain dynamics of the worms was analyzed (Table 3 ). Accordingly, the leaves of the new selection numbers of mulberry had a significant positive effect on the growth dynamics of "Ipakchi 1" x "Ipakchi 2" industrial hybrid worms at 4-5 years of age. According to the results of 2015, the highest growth dynamics was determined in the variants consuming leaves of numbers №3-02 (0.563 g) and №7-02 $(0.531 \mathrm{~g})$, while in 2016 and 2017 the figures were №3-02 (0.634-0.646 g) and the high results of selection numbers №7-02 $(0.643-0.646 \mathrm{~g})$ were noted compared to the "Tajik seedless" variety. The three-year (2015-2017) results of the comparative "Tajik seedless" variety were $0.389 \mathrm{~g}, 0.627 \mathrm{~g}$ and $0.624 \mathrm{~g}$, respectively. The growth dynamics of the 
weight of these worms certainly indicate the effectiveness of the selection numbers of candidates for the new variety (Table 3 ).

Table 3. Worm weight growth dynamics of Ipakchi 1 x Ipakchi 2 hybrid (2015-2017)

\begin{tabular}{|c|c|c|c|}
\hline $\begin{array}{c}\text { Selection numbers of } \\
\text { mulberry }\end{array}$ & $\begin{array}{l}\text { IV- the weight of the } \\
\text { worms } \\
\text { on the first day of age } \\
\bar{X}{ }_{ \pm S} \bar{x}, \Gamma\end{array}$ & $\begin{array}{c}\text { V- the weight of the } \\
\text { worms } \\
\text { on the first day of age } \\
\bar{X}{ }_{ \pm S} \bar{X}, \Gamma\end{array}$ & $\begin{array}{l}\text { Worm growth } \\
\text { dynamics } \\
\bar{X}_{ \pm \mathrm{S}} \bar{x}, \mathbf{\Gamma}\end{array}$ \\
\hline №2-02 & $0.250^{*} \pm 0.014$ & $0.826^{*} \pm 0.059$ & $0.607^{*} \pm 0.074$ \\
\hline №3-02 & $0.291^{*} \pm 0.021$ & $0.854^{*} \pm 0.098$ & $0.614^{*} \pm 0.067$ \\
\hline №4-02 & $0.252^{*} \pm 0.017$ & $0.817^{*} \pm 0.080$ & $0.565^{* *} \pm 0.063$ \\
\hline №5-02 & $0.273^{*} \pm 0.021$ & $0.851^{*} \pm 0.070$ & $0.578^{*} \pm 0.028$ \\
\hline №7-02 & $0.319^{*} \pm 0.006$ & $0.919^{*} \pm 0.040$ & $0.607^{*} \pm 0.037$ \\
\hline $\begin{array}{l}\text { The comparative } \\
\text { "Tajik seedless" } \\
\text { variety }\end{array}$ & $0.213 \pm 0.017$ & $0.756 \pm 0.089$ & $0.546 \pm 0.078$ \\
\hline
\end{tabular}

It was important to analyze the weight of worms at this age, because the maximum peak of mulberry silkworm feeding was fell on these days. If the mulberry leaves are nutritious and of good quality during this period, the ground will be laid for the cultivation of abundant and quality cocoons. Table 4 showed that the weight of 5-year-old worms of the two hybrids was 3.92-3.86 $\mathrm{g}$ at the selection number №2-02 based on a 3-year average, at №3-02 selection number it was 4.41-4.45 g, at №4-02 selection number it was 4.13-4.16 g, at №5-02 selection number it was 4.25-4.32 g, at №7-02 it was 4.29-4.33 g, and it was 4.00-4.06 $\mathrm{g}$ in the comparative variant. The performance of the new numbers was found to be $3.3-10.3 \%$ higher than that of the comparator.

Table 4. Worms fed on the leaves of different mulberry varieties gain weight on the fifth day of the fifth year

\begin{tabular}{|c|c|c|c|c|c|}
\hline \multirow[b]{2}{*}{$\begin{array}{c}\text { Mulberry } \\
\text { varieties }\end{array}$} & \multirow[b]{2}{*}{ Years } & \multicolumn{4}{|c|}{ V-the weight of the worms on the fifth day of age, years } \\
\hline & & 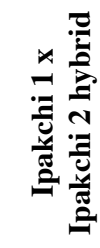 & 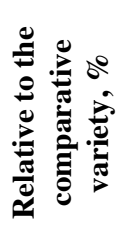 & 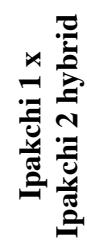 & 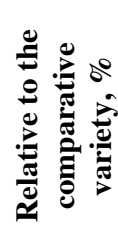 \\
\hline \multirow{2}{*}{ №2-02 } & 2015 & 3.99 & 100.8 & 3.91 & 100.3 \\
\hline & 2016 & 3.81 & 93.3 & 3.80 & 95.0 \\
\hline
\end{tabular}




\begin{tabular}{|c|c|c|c|c|c|}
\hline & 2017 & 3.26 & 93.8 & 3.87 & 93.9 \\
\hline & $\bar{X}_{ \pm \mathrm{S}} \bar{x}$ & $3.68 \pm 0.21$ & 96.6 & $3.86 \pm 0.03$ & 96.5 \\
\hline \multirow{4}{*}{$\begin{array}{c}\text { №3-02 } \\
\text { (Jararik-9) }\end{array}$} & 2015 & 4.28 & 108.1 & 4.21 & 107.9 \\
\hline & 2016 & 4.39 & 104.0 & 4.32 & 108.0 \\
\hline & 2017 & 4.69 & 111.1 & 4.70 & 114.1 \\
\hline & $\bar{X} \pm \mathrm{S} \bar{x}$, & $4.45 \pm 0.12$ & 109.6 & $4.41 \pm 0.14$ & 110.3 \\
\hline \multirow{4}{*}{ №4-02 } & 2015 & 4.00 & 101.0 & 3.98 & 102.1 \\
\hline & 2016 & 4.18 & 99.1 & 4.11 & 99.8 \\
\hline & 2017 & 4.31 & 102.1 & 4.29 & 104.1 \\
\hline & $\bar{X} \pm \mathrm{S} \bar{x}$ & $4.16 \pm 0.09$ & 102.5 & $4.13 \pm 0.09$ & 103.3 \\
\hline \multirow{4}{*}{ №5-02 } & 2015 & 4.12 & 104.0 & 4.08 & 104.6 \\
\hline & 2016 & 4.37 & 107.1 & 4.30 & 107.5 \\
\hline & 2017 & 4.48 & 106.2 & 4.37 & 106.1 \\
\hline & $\bar{X}_{ \pm \mathrm{S}} \bar{x}$ & $4.32 \pm 0.10$ & 106.4 & $4.25 \pm 0.08$ & 106.3 \\
\hline \multirow{4}{*}{$\begin{array}{c}\text { №7-02 } \\
\text { (Jararik-10) }\end{array}$} & 2015 & 4.11 & 103.8 & 4.00 & 102.6 \\
\hline & 2016 & 4.39 & 107.6 & 4.31 & 107.8 \\
\hline & 2017 & 4.48 & 106.2 & 4.57 & 110.9 \\
\hline & $\bar{X}_{ \pm \mathrm{S}} \bar{x}$ & $4.33 \pm 0.11$ & 106.7 & $4.29 \pm 0.16$ & 107.3 \\
\hline \multirow{4}{*}{$\begin{array}{c}\text { The } \\
\text { comparati } \\
\text { ve "Tajik } \\
\text { seedless" } \\
\text { variety }\end{array}$} & 2015 & 3.96 & 100.0 & 3.90 & 100.0 \\
\hline & 2016 & 4.08 & 100.0 & 4.00 & 100.0 \\
\hline & 2017 & 4.22 & 100.0 & 4.12 & 100.0 \\
\hline & $\bar{X}_{ \pm \mathrm{S}} \bar{x}$ & $4.08 \pm 0.07$ & 100.0 & $4.00 \pm 0.06$ & 100.0 \\
\hline
\end{tabular}

\subsection{Influence of new mulberry varieties on silkworm larval period duration}

Mulberry silkworm undergoes a 5-year growth period during the larval stage. This age range is alternated with peeling. The duration of the young depends mainly on air temperature, humidity and, most importantly, the quantity and quality of leaves. In addition, the duration of youth during the worm period also depends on the silkworm breed. In particular, one of the important features of mulberry silkworm industrial hybrids imported from China in recent years is that their worm life is shorter than that of local hybrids. However, this important feature can also be achieved by increasing the nutritional and nutritional value of mulberry. It was determined that there was the effect of the leaves of new varieties of mulberry on the duration of 1-5 years of age of hybrid worms. This symbol is as important as any other economic symbol. This is because even if the worm cycle is shortened by an average of 1-2 days (while maintaining a high level of viability and cocoon productivity), it will result in a certain convenience and economic efficiency in the worm feeding process. This is primarily manifested in labor costs and time savings in feeding worms, as well as a reduction in the consumption of leaf mass. 
The results obtained were almost the same in both hybrids, i.e. the worm period was shortened to 1-4 days due to the presence of sufficient nutrients in the leaves. In the 2015 worm feeding season, worms treated with leaves of selection number №3-02 were introduced to cocoon packing in 26 days, while in the comparative variant, the worms were reared for 30 days. In 2016, the worms of selection number №7-02 were fed for 26.5 days, and in control, it was 30 days. The results of 2017 were 26.5 days and 29 days, respectively. It was proven that the selection numbers, №3-02 and №7-02 in the selection material of the candidate for the new variety, fully met the requirements for mulberry varieties not only with leaf yield, but also with its nutritional value and good assimilation by worms (Table 5). It is possible to save every day during the worm feeding period and at the same time maintain a high level of worm viability and cocoon productivity with great economic benefits. In the science and practice of silkworm breeding, certain scientific results were achieved in shortening the worm period on the basis of air temperature and various technologies of worm farming. However, it was identified that these technologies shortened the silkworm period and slightly reduce the silkworms.

Table 5. Duration of the silkworm hybrids "Ipakchi 1" $x$ "Ipakchi 2" and "Ipakchi 2" x "Ipakchi 1" (2015-2017)

\begin{tabular}{|c|c|c|c|c|}
\hline \multirow{2}{*}{$\begin{array}{c}\text { Selection } \\
\text { numbers of } \\
\text { mulberry }\end{array}$} & $\begin{array}{c}\text { "Ipakchi 2" x "Ipakchi 1" } \\
\text { Total duration } \\
\text { of the worm } \\
\text { period }\end{array}$ & $\begin{array}{c}\text { Relative to } \\
\text { comparative } \\
\text { variety, \% }\end{array}$ & $\begin{array}{c}\text { Total duration } \\
\text { of the worm } \\
\text { period }\end{array}$ & $\begin{array}{c}\text { "Ipakchi 1" x "Ipakchi 2" } \\
\text { Remparive to } \\
\text { variety, \% }\end{array}$ \\
\hline №2-02 & $30 \pm 0.57$ & 101.0 & $30 \pm 0.81$ & 101.7 \\
\hline №3-02 & $26.3 \pm 0.06$ & 88.6 & $26.7 \pm 0.44$ & 90.5 \\
\hline №4-02 & $28.2 \pm 0.16$ & 95.0 & $28.7 \pm 0.33$ & 97.3 \\
\hline №5-02 & $27.8 \pm 0.60$ & 93.6 & $27.0 \pm 0.50$ & 91.5 \\
\hline №7-02 & $27.3 \pm 0.44$ & 91.9 & $27.2 \pm 0.80$ & 92.2 \\
\hline $\begin{array}{c}\text { The } \\
\text { comparative } \\
\text { “Tajik } \\
\text { seedless" } \\
\text { variety }\end{array}$ & $29.7 \pm 0.33$ & 100.0 & $29.5 \pm 0.28$ & 100.0 \\
\hline
\end{tabular}

\subsection{Coefficient of eating the leaves of new mulberry varieties by hybrid worms}

Mulberry silkworm eats less of the given feed at the beginning and end of each age than in the middle. The rate of leaf erosion increases with age. In young children, worms consume up to $30 \%$ of the given feed, while in the fifth year this figure can be up to $75 \%$. If the feed erosion coefficient depends first on the quality of the leaves, then it depends on the correct adherence to the agronomic techniques of worm feeding. The uneaten leaf remnant consists of true leaves at a young age, while in adults the leaf band and thick veins remain. This section is mostly high in fiber and ash. The question of which leaf is better and more 
useful has long been a problem for silk scientists. Hence, the difference between the number of leaves given to the worms and the number of leaves eaten by them is an indicator of the nutrient uptake coefficient. The great silk scientist E. Mikhailov noted in his research that this figure is around $65-70 \%$ [7]. The higher this value, the healthier the silkworms, the normal growth and development, and the heavier and better the cocoon yield. All the facts and evidence mentioned above were calculated based on the number of leaves in a box worm $1200 \mathrm{~kg}$. In research and practice, foreign silkworms and catchers do not weigh as much as 1,200 kg per box of worms in Uzbekistan.

It was determined the leaf absorption coefficient by cultivating "Ipakchi 1" $\mathrm{x}$ "Ipakchi 2"and "Ipakchi 2" x "Ipakchi 1" industrial hybrid worms with leaves of new mulberry varieties based on the consumption of $900 \mathrm{~kg}$ of leaves per box worm (Table 6). It was found that the leaves of the newly created mulberry varieties were well assimilated by the hybrid worms. Among the selection numbers, the coefficient of assimilation of leaves of numbers №3-02 and №7-02 (“Jararik-9" and "Jararik-10") in 2015 was 69.2\%, and 62.7\%, followed by $74.3 \%$ and $75.7 \%$ in 2016 , and in 2017 , it was $72.7 \%$ and $76.1 \%$, respectively. However, it was in the range of $64.5-71.3 \%$ in other surveyed numbers, which accepted as quite high result (Tables 6-8).

The comparative "Tajik seedless" variety, the coefficient of leaf eating in 2015-2017 was $64.0 \%, 64.7 \%$ and $61.2 \%$, respectively. The analysis of age showed that the leaf eating coefficient of the fifth young worms was maintained at 76.3-83\% at number №3-02 and $70.7-82.9 \%$ at selection number №7-02. Of course, the high rate of leaf assimilation at the age of five ensures, firstly, that the worms were well saturated with nutrients, and secondly, that the biosynthesis of silk fluid, which occurs in the silk gland, was accelerated. Noteworthy, among the new selection numbers №3-02 and №7-02 the coefficient of assimilation was significantly superior to other selection numbers and the comparative "Tajik seedless" variety.

Table 6. Coefficient of leaf eating of new mulberry varieties ( 1500 worms fed at therate of $900 \mathrm{~kg}$ of leaves per 1 box of "Ipakchi 1" $\mathrm{x}$ "Ipakchi " 2 hybrids in 2015)

\begin{tabular}{|c|c|c|c|c|}
\hline Age of worms & $\begin{array}{c}\text { The amount leaf } \\
\text { given to worms }\end{array}$ & $\begin{array}{c}\text { Weight of } \\
\text { cocoon }\end{array}$ & $\begin{array}{c}\text { Amount of food } \\
\text { eaten, kg }\end{array}$ & $\begin{array}{c}\text { Coefficient of } \\
\text { eating food, \% }\end{array}$ \\
\hline \multicolumn{5}{|c|}{ № 2-02 } \\
\hline I-II-ages & 0.7 & 0.48 & 0.22 & 31.4 \\
\hline III-age & 1.29 & 0.87 & 0.42 & 32.6 \\
\hline IV-age & 4.41 & 2.71 & 1.7 & 38.5 \\
\hline V-age & 23.6 & 6.1 & 17.5 & 74.2 \\
\hline Total & 30 & 10.2 & 19.8 & 66.0 \\
\hline \multicolumn{7}{|c|}{ № 03-02 (“Jararik-9”) } \\
\hline I-II-ages & 0.66 & 0.42 & 0.24 & 36.4 \\
\hline III-age & 1.32 & 0.83 & 0.49 & 37.1 \\
\hline IV-age & 4.0 & 2.2 & 1.8 & 45.0 \\
\hline V-age & 24.0 & 5.7 & 18.3 & 76.3 \\
\hline Total & 30 & 9.2 & 20.8 & 69.2 \\
\hline \multicolumn{7}{|l|}{ № 4-02 } \\
\hline I-II-ages & 0.66 & 0.44 & 0.20 & 30.3 \\
\hline
\end{tabular}




\begin{tabular}{|c|c|c|c|c|}
\hline III-age & 1.32 & 0.93 & 0.39 & 29.5 \\
\hline IV-age & 4.0 & 2.5 & 1.5 & 37.5 \\
\hline V-age & 24.0 & 7.3 & 16.7 & 69.6 \\
\hline Total & 30.0 & 10.5 & 19.5 & 65.0 \\
\hline \multicolumn{5}{|c|}{ № 7-02 (“Jararik-10”) } \\
\hline I-II-ages & 0.66 & 0.38 & 0.21 & 31.8 \\
\hline III-age & 1.32 & 0.82 & 0.50 & 37.9 \\
\hline IV-age & 4.0 & 2.12 & 1.88 & 49.8 \\
\hline V-age & 24.0 & 6.1 & 18.1 & 75.0 \\
\hline Total & 30.0 & 9.4 & 20.6 & 68.8 \\
\hline \multicolumn{5}{|c|}{ № 5-02 } \\
\hline I-II-ages & 0.66 & 0.47 & 0.19 & 33.9 \\
\hline III-age & 1.21 & 0.9 & 0.31 & 25.6 \\
\hline IV-age & 4.30 & 2.9 & 1.4 & 32.6 \\
\hline V-age & 23.9 & 7.0 & 16.9 & 70.7 \\
\hline Total & 30 & 11.2 & 18.8 & 62.7 \\
\hline \multicolumn{7}{|c|}{ The comparative “Tajik seedless” variety } \\
\hline I-II-ages & 0.66 & 0.46 & 0.20 & 30.3 \\
\hline III-age & 1.32 & 0.94 & 0.38 & 28.8 \\
\hline IV-age & 4.0 & 2.31 & 1.69 & 42.3 \\
\hline V-age & 24.0 & 7.5 & 16.5 & 68.8 \\
\hline Total & 30 & 10.8 & 18.8 & \\
\hline
\end{tabular}

Table 7. Coefficient of leaf eating of new mulberry varieties ( 1500 worms fed at therate of $900 \mathrm{~kg}$ of leaves per 1 box of "Ipakchi 1" x "Ipakchi "2 hybrids in 2016)

\begin{tabular}{|c|c|c|c|c|}
\hline Age of worms & $\begin{array}{c}\text { The amount leaf } \\
\text { given to worms }\end{array}$ & $\begin{array}{c}\text { Weight of } \\
\text { cocoon }\end{array}$ & $\begin{array}{c}\text { Amount of food } \\
\text { eaten, kg }\end{array}$ & $\begin{array}{c}\text { Coefficient of } \\
\text { eating food, \% }\end{array}$ \\
\hline \multicolumn{5}{|c|}{ № 2-02 } \\
\hline I-II-ages & 0.66 & 0.41 & 0.29 & 41.4 \\
\hline III-age & 1.32 & 0.78 & 0.51 & 39.5 \\
\hline IV-age & 4.0 & 2.52 & 1.89 & 42.9 \\
\hline V-age & 24.0 & 4.9 & 18.7 & 79.2 \\
\hline Total & 30 & 8.6 & 21.4 & 71.3 \\
\hline \multicolumn{7}{|c|}{ № 03-02 (“Jararik-9”) } \\
\hline I-II-ages & 0.66 & 0.4 & 0.30 & 42.9 \\
\hline III-age & 1.32 & 0.78 & 0.51 & 39.5 \\
\hline IV-age & 4.0 & 2.54 & 1.87 & 42.4 \\
\hline V-age & 24.0 & 4.0 & 19.6 & 83.1 \\
\hline Total & 30 & 7.7 & 22.3 & 74.3 \\
\hline
\end{tabular}




\begin{tabular}{|c|c|c|c|c|}
\hline \multicolumn{5}{|c|}{ № 4-02 } \\
\hline I-II-ages & 0.66 & 0.44 & 0.22 & 33.3 \\
\hline III-age & 1.32 & 0.85 & 0.47 & 35.6 \\
\hline IV-age & 4.0 & 2.4 & 1.6 & 40.0 \\
\hline V-age & 24.0 & 6.8 & 17.2 & 71.7 \\
\hline Total & 30.0 & 10.5 & 19.5 & 65.0 \\
\hline \multicolumn{5}{|c|}{ № 5-02 } \\
\hline I-II-ages & 0.66 & 0.44 & 0.22 & 33.3 \\
\hline III-age & 1.32 & 0.93 & 0.39 & 29.5 \\
\hline IV-age & 4.0 & 2.55 & 1.45 & 36.3 \\
\hline V-age & 24.0 & 6.7 & 17.3 & 72.1 \\
\hline Total & 30.0 & 10.64 & 19.36 & 64.5 \\
\hline \multicolumn{5}{|c|}{ № 03-02 (“Jararik-10”) } \\
\hline I-II-ages & 0.66 & 0.39 & 0.27 & 40.9 \\
\hline III-age & 1.32 & 0.77 & 0.55 & 41.7 \\
\hline IV-age & 4.0 & 2.0 & 3.0 & 50.0 \\
\hline V-age & 24.0 & 4.1 & 19.9 & 82.9 \\
\hline Total & 30.0 & 7.3 & 22.7 & 75.7 \\
\hline \multicolumn{5}{|c|}{ The comparative "Tajik seedless" variety } \\
\hline I-II-ages & 0.66 & 0.44 & 0.22 & 33.3 \\
\hline III-age & 1.32 & 0.91 & 0.41 & 31.1 \\
\hline IV-age & 4.0 & 2.28 & 1.72 & 4.3 \\
\hline V-age & 24.0 & 7.0 & 17.0 & 70.8 \\
\hline Total & 30.0 & 10.6 & 19.4 & 64.7 \\
\hline
\end{tabular}

Table 8. Coefficient of leaf eating of new mulberry varieties ( 1500 worms fed at therate of $900 \mathrm{~kg}$ of leaves per 1 box of "Ipakchi 1" x "Ipakchi "2 hybrids in 2017)

\begin{tabular}{|c|c|c|c|c|}
\hline Age of worms & $\begin{array}{c}\text { The amount leaf } \\
\text { given to worms }\end{array}$ & $\begin{array}{c}\text { Weight of } \\
\text { cocoon }\end{array}$ & $\begin{array}{c}\text { Amount of food } \\
\text { eaten, kg }\end{array}$ & $\begin{array}{c}\text { Coefficient of } \\
\text { eating food, \% }\end{array}$ \\
\hline \multicolumn{5}{|c|}{ № 2-02 } \\
\hline I-II-ages & 0.66 & 0.36 & 0.30 & 45.5 \\
\hline III-age & 1.32 & 0.75 & 0.57 & 43.1 \\
\hline IV-age & 4.0 & 3.43 & 1.96 & 49.0 \\
\hline V-age & 24.0 & 6.0 & 18.0 & 75.0 \\
\hline Total & 30.0 & 9.17 & 20.83 & 69.4 \\
\hline \multicolumn{7}{|l|}{ № 03-02 (“Jararik-9”) } \\
\hline I-II-ages & 0.66 & 0.33 & 0.33 & 50.0 \\
\hline III-age & 1.32 & 0.73 & 0.59 & 44.7 \\
\hline IV-age & 4.0 & 2.0 & 2.0 & 5.0 \\
\hline
\end{tabular}




\begin{tabular}{|c|c|c|c|c|}
\hline V-age & 24.0 & 4.1 & 19.9 & 82.9 \\
\hline Total & 30.0 & 7.18 & 22.82 & 72.7 \\
\hline \multicolumn{5}{|c|}{ № 4-02 } \\
\hline I-II-ages & 0.66 & 0.43 & 0.23 & 34.8 \\
\hline III-age & 1.32 & 0.94 & 0.38 & 28.8 \\
\hline IV-age & 4.0 & 2.2 & 1.8 & 45.0 \\
\hline V-age & 24.0 & 7.1 & 16.9 & 70.4 \\
\hline Total & 30.0 & 10.69 & 19.31 & 64.4 \\
\hline \multicolumn{5}{|c|}{ № 5-02 } \\
\hline I-II-ages & 0.66 & 0.39 & 0.27 & 40.9 \\
\hline III-age & 1.32 & 0.91 & 0.41 & 31.1 \\
\hline IV-age & 4.0 & 2.42 & 1.58 & 39.5 \\
\hline V-age & 24.0 & 6.0 & 18.0 & 79.0 \\
\hline Total & 30.0 & 9.74 & 20.26 & 67.5 \\
\hline \multicolumn{5}{|c|}{ № 03-02 (“Jararik-10”) } \\
\hline I-II-ages & 0.66 & 0.33 & 0.33 & 50.0 \\
\hline III-age & 1.32 & 0.73 & 0.59 & 44.7 \\
\hline IV-age & 4.0 & 1.8 & 2.2 & 55.0 \\
\hline V-age & 24.0 & 4.3 & 19.7 & 82.1 \\
\hline Total & 30.0 & 7.18 & 22.82 & 76.1 \\
\hline \multicolumn{5}{|c|}{ The comparative "Tajik seedless" variety } \\
\hline I-II-ages & 0.66 & 0.47 & 0.19 & 28.8 \\
\hline III-age & 1.32 & 0.96 & 0.36 & 27.3 \\
\hline IV-age & 4.0 & 2.19 & 1.81 & 45.3 \\
\hline V-age & 24.0 & 8.0 & 17.0 & 66.7 \\
\hline Total & 30.0 & 11.64 & 18.36 & 61.2 \\
\hline
\end{tabular}

\section{Conclusion}

The results of the chemical composition of new high-yielding varieties of mulberry showed that the number of nutrients in the leaves of selection numbers was different, and the chemical composition of leaves was directly depended on their genotype and origin. Furthermore, the leaves of the new selection numbers of mulberry №3-02 (0.563 grams) and №7-02 (0.531 grams) had a significant positive effect on the growth dynamics of worms in "Ipakchi 1" x "Ipakchi 2" industrial hybrid at the age of 4-5 years.

The results obtained also depicted that the selection numbers of fresh mulberry leaves had a positive effect on the growth and development of silkworms. Moreover, it was found that it was possible to save every day during the worm feeding period, that was, to shorten the worm period, and at the same time to maintain a high level of worm viability and cocoon productivity. The pertinent results of the experiments on the consumption of $900 \mathrm{~kg}$ 
of leaves per box of worms, showed that the new selection numbers №3-02 and №7-02 had a significant advantage over other selection numbers and the comparative "Tajik seedless" variety.

\section{References}

1. V. S. Ramya, S. Chandrashekar, Int. J. Curr. Microbiol. App. Sci 9, 3 (2020)

2. X. He, X. Chen, X. Ou, L. Ma, W. Xu, K. Huang, International Journal of Food Science \& Technology 55, 2 (2020)

3. K. Suresh, H. Yallappa, A. Pappachan, M. Laskar, G. R. Manjunath, D. Chakravarthy, V. Sivaprasad, Int. J. Curr. Microbiol. App. Sci 10(01), 2762-2778 (2017)

4. S. Parida, K. Rayaguru, J. Panigrahi, Journal of Natural Remedies 21, 5 (2020)

5. Presidential Decree No.4947 of the Republic of Uzbekistan on "The strategy of action for the development of the republic of Uzbekistan" on February 7 (2017)

6. Presidential Resolution No.2856 of the Republic of Uzbekistan on "Measures to organize the activities of UZBEKIPAKSANOAT" on March 29 (2017)

7. Presidential Resolution No.3616 of the Republic of Uzbekistan on "Additional measures for further development of the stage network" on March 20 (2018).

8. N. Axmedov, Ch. Bekkamov, N. Rajabov, Zoo-veterinary, 9 (2020).

9. U. N. Axmedov, Zoo-veterinary, 44 (2016) 